\title{
Frequency and Characteristics of Common Infectious Disease Among Children under 5 Years Old Presenting at Giza Family Health Center during 2013
}

Shaimaa Mohamed Abdou*,Mohamed Y. El Awady**,Nahla F. Abo El Ezz**,Dina N. K. Boulos**

*Giza Family Health Center; **Department of Community Environmental and Occupational Medicine, Faculty of Medicine, Ain Shams University

Received: June 2016 Accepted: September 2016

\begin{abstract}
Background: Communicable disease epidemiology is closely linked to pathogen ecology, environmental and social determinants, economic factors, as well as the state of country development. Objectives: This study was conducted to measure the frequency, seasonal variations and the characteristics of common infectious diseases among children under 5 years old at Giza FHC during 2013. Patient and Methods: Data was collected from files of 2635 children included in the study. Data was statistically described and correlated with each other. Result: The history of infectious diseases in the present study was recorded in $86.4 \%$ of the total records of children under 5 years in the family health care center. The most prevalent types of infectious diseases in recent study were upper respiratory tract infections $(29.5 \%)$ and oro-pharyngeal infections (19.7\%) followed by skin infections (12.7\%). Parental employment, income and particularly work status of the mother have been found to be associated with the occurrence of infectious diseases in childhood. Also, the parents with higher level of education had children with fewer infectious diseases compared with parents with less education. Conclusion: The present study had identified a high prevalence of infectious diseases among under-fives. It also pointed out various sociodemographic and environmental modifiable risk factors which can be tackled by effective education of the community. Recommendation: The study recommended further studies in Egypt in many PHC centers to determine the most prevalent infectious diseases among children under 5 years old and to achieve proper health education programs as a trial for prevention.
\end{abstract}

Key words: Common infectious diseases, family health center, under 5 infections, Giza governorate.

Corresponding Author: Shaimaa Mohamed Abdou Email: buny_fruity@yahoo.com

\section{Introduction}

Communicable disease is an illness due to a specific infectious agent or its toxic products that arises through transmission of that agent or its products from an infected person, animal, or reservoir to a susceptible host, either directly or indirectly through an intermediate plant or animal host, vector, or the inanimate environment. ${ }^{(1)}$

Respiratory tract infections are substantial health problem in many developing countries .(2)(3) and lower respiratory tract infections are an important cause of death among children under 2 years of age..$^{(4)(5)}$

Gastroenteritis is a common cause of morbidity in young children. Studies from North America and elsewhere indicate that each year there are between 1.2 and 2.5 episodes of gastroenteritis per child aged 5 years or less. ${ }^{(6)(7)(8)}$ Proper evaluation of health problems, correct diagnosis and suitable treatment are the key factors in reducing the illness burden. This enhances the 
quality of life of the patients, which is of utmost importance. ${ }^{(9)}$

Since infectious diseases affect a child's health, especially children less than five years and have a direct relationship with some environmental and social factors, this study will measure the frequency of infectious diseases among children under five years, and identify sociodemographic and seasonal factors that affect those infectious diseases.

Research Hypothesis: Frequency of common infectious diseases among children under 5 years old at Giza FHC during 2013 is less than national frequency based on clinical experience.

Research Question: What is the frequency of different infectious diseases affecting children under 5 years old at Giza FHC during 2013?

The ultimate goal of this work is to decrease morbidity and mortality among children under 5 years old.

Objectives: To Measure the frequency of common infectious disease (Acute respiratory infections, diarrhea, etc.) among children under 5 years old at Giza FHC during 2013 and to Identify seasonal variation and different characteristics of such infectious disease among children under 5 years old at Giza FHC during 2013.

\section{Patient and Methods}

Type of the study: descriptive study from records.

Study population: All patients' files (including children under 5 years old) which were 2635 children attending to Giza primary health care center during

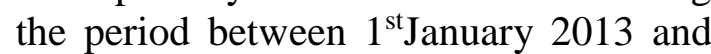
$31^{\text {st }}$ December 2013 were included in the study.

Study setting: All files were reviewed using extraction sheet for detection of: Presentation date to determine seasonal variations, socio-demographic data, Diagnosis.

Ethical consideration: Confidentiality and non-disclosure of identities, data and results were considered. Administrative approvals, approval of ethical committee were obtained.

Data management and statistical analysis: Data was collected, revised, coded and introduced to a Personal Computer (PC) statistical analysis using Statistical Package for the Social Sciences (SPSS) version 16 was performed. Quantitative data e.g. age are presented as mean \pm standard deviation. to compare such data between two groups Independent $t$ test was used for parametric data and Mann-Whitney for non-parametric data. Qualitative data e.g. sex, are presented as count and percentage. Chi-squared test is used to compare such data between two or more groups.

\section{Result}

A total of 2635 children below 5 years of age who were admitted to Giza primary health care center during the period between $1^{\text {st }}$ January 2013 and $31^{\text {st }}$ December 2013 were studied to determine frequency, socio demographic characteristics and seasonal variations of common infectious diseases.

The study shows that infectious diseases comprised $86.4 \%$ of the total records of diagnosis of children under 5 years in the family health care center. And also shows that the highest prevalence of infectious diseases are upper respiratory tract infections and Oro-pharyngeal infections.(Table 1)

There is a higher mean age for children with vaccine preventable infectious diseases and children with urinary tract infections compared to other groups and the difference is highly significant statistically. (Table 2)

The study shows that the highest frequency of infectious diseases was in winter $(39.7 \%)$ followed by Autumn $(27.2 \%)$ (Figure1). There were higher percentages of pneumonia in winter and spring compared to other seasons, higher percentage of upper respiratory tract 
infections in winter compared to other seasons. And higher percentage of GE (gastroenteritis), parasitic infections, skin infections in summer months compared to other seasons and the difference is highly significant statistically. (Table 3) There is higher percentage of pneumonia, gastrointestinal and urinary tract infections among children of illiterate, read and write mothers (Table 4).

The study shows a higher percentage of GIT infectious diseases among subjects in families with low income, higher percentage of Oro-pharyngeal diseases, vaccine preventable diseases among subjects in families with high income and the difference is highly significant statistically. (Table 5)

\section{Discussion}

In the present study, the percent of infectious diseases comprised $86.4 \%$ of the total records of diseased children under 5 years in the family health care center. In consistent with the current results, the overall prevalence of infectious diseases was high and noted about $75 \%$ and this extensive morbidity from infectious diseases may have had adverse effects on the growth and development of the children. ${ }^{(10)}$ Also, in Pakistan there was a high frequency of infectious diseases that consisted about $95 \%$ in children less than 5 years.$^{(11)}$ and this high prevalence could be due to Pakistan low economic and environmental factors.

In the current study, the distribution of infectious diseases that were diagnosed among children under 5 years in the family health care center was studied. The results showed that the highest percentage of infectious disease in the studied children was upper respiratory tract infections (29.5\%) and Oropharyngeal $(19.7 \%)$ followed by skin infections $(12.7 \%){ }^{(12)}$ In rural Kenya the studied children aged less than five years, $30-40 \%$ had diarrhea and (44\%) had fever while a larger proportion (approaching 90\%) of pneumonia episodes. Also, in the 2003 Demographic and Health Survey, rates of prevalence for acute illness episodes among young children were $18 \%$ for ARI, $41 \%$ for fever, and $16 \%$ for diarrhea.$^{(13)}$ these results differ from the present results due to seeking of healthcare at health facilities and hospitals varied by syndrome, severity of illness, and characteristics of the patient.

There is a higher mean age for children with vaccine preventable infectious diseases approximately 4 years old and this higher age may be due to contact of children with others in school or nursery. In accordance with our results, the overall sero-prevalence rate of chicken pox among children was $15.5 \%$ in the 9month to 4-year-old children in tropical country. ${ }^{(14)}$

The prevalence of infectious diseases among children by seasons of the year was the highest in winter $39.7 \%$ followed by autumn $27.2 \%$. The pattern of infectious diseases vary greatly among children during the seasons of the year and infection occurs in the winter months, when vitamin D levels and immunity are lower, there might be a greater risk for developing infectious complications. $^{(15)}$

According to mother and father education association to the classification of infectious diseases, there was a statically significant difference. There was higher percentage of pneumonia, skin infections, GIT infectious diseases among children with illiterate or read and write parents. These results are in consistence with many studies which revealed that parents with higher level of education had children with fewer infectious diseases compared with parents with less education in Columbia, South Carolina of the USA. ${ }^{(16)}$ This could be attributed to that illiterate parents don't have the requested knowledge about sanitations, disease complications and appropriate type of medication. 


\section{Conclusion and Recommendation}

In conclusion, the present study had identified a high prevalence of infectious diseases among under-fives. It also pointed out various socio-demographic and environmental modifiable risk factors which can be tackled by effective education of the community. In this study, the age,season of the year and breast feeding significantly affect the distribution of infectious diseases in children less than 5 years. The study recommended further studies in Egypt in many PHC centers to determine the most prevalent infectious diseases among children under 5 years old and to achieve proper health education programs as a trial for prevention.

\section{References:}

1. Saker L, Lee K, Cannito B, Gilmore A, Campbell-Lendrum D. (2004): Globalization and infectious diseases: A review of the linkages, Special Topic No. 3. TDR/STR/SEB/ST/042, UNICEF, UNDP, World Bank, WHO, Geneva.2004

2. Zaman S, Jalil F, Karlberg J.(1993) : Early child health in Lahore, Pakistan. VI Morbidit . Acta Paediatr 1993; 390 (suppl): 63-78.

3. Muhe L. (1994): Child health and acute respiratory infections in Ethiopia: epidemiology for prevention and control. Ph.D. Thesis, Umea University, Umea,1994.

4. Berman S.(1991) Epidemiology of acute respiratory infections in children of developing countries. Rev Infect. Dis.1991; 13:454-462.

5. Bartlett AV, Bocaletti PME, Bocaletti MA.(1991): Neonatal morbidity and mortality in a rural Guatemalan community:the importance of infectious diseases and their management. Pediatr Infect Dis J 1991;10:752-757.

6. Glass R, Lew J, Gangarosa R, LeBaron C, Ho M.(1991): Estimates of morbidity and mortality rates for diarrheal diseases in American children. J Pediatr 1991; 118: $27-$ 33.

7. Payment P, Siemiatycki J, Richardson L, et al.(1997): A prospective epidemiological study of gastro-intestinal health effects due to the consumption of drinking water. Int $\mathbf{J}$ Environ Hlth Res 1997; 7: 5-31.

8. Herikstad H1, Yang S, Van Gilder TJ, Vugia D, Hadler J, Blake P, Deneen V, Shiferaw B, Angulo FJ.( 2002): A population-based estimate of the burden of diarrhoeal illness in the United States: FoodNet, 1996-7. Epidemiol Infect.2002;129(1):9-17.

9. http://www.who.int/gho/countries/egy/country -profiles/en/index.html (accessed 2012).

10. Black RE, Brown KH, Becker S, Yunus M. (1982): Longitudinal studies of infectious diseases and physical growth of children in rural bangladesh: I. Patterns of morbidity. American Journal of Epidemiology. 1982; 115: 305-314.

11. Mehnaz A.(2009): Infectious diseases in children-still leads. J Pak Med Assoc 2009; 59: 425-426.

12. Burton DC, Flannery B, Onyango B, Larson C, Alaii J, Zhang X, Hamel MJ, Breiman RF, Feikin DR.(2011): Healthcare-seeking behaviour for common infectious disease-related illnesses in rural kenya: A community-based house-to-house survey. Journal of Health, Population, and Nutrition. 2011; 29: 61-70.

13.13) Kenya Central Bureau of Statistics. (2004): Kenya demographic and health survey 2003: key findings. Calverton, MD: Kenya Central Bureau of Statistics; 2004. p. 21

14. Lolekha S, Tanthiphabha W, Sornchai P, Kosuwan P, Sutra S, Warachit B, ChupUpprakarn S,Hutagalung Y, Weil J, Bock HL.(2001): Effect of climatic factors and population density on varicella zoster virus epidemiology within a tropical country. Am J Trop Med Hyg. 2001; 64: 131-136.

15. Cannell JJ, Vieth R, Umhau JC, Holick MF, Grant WB, Madronich S, Garland CF, Giovannucci E.(2006): Epidemic influenza and vitamin d. Epidemiol Infect 2006; 134: 11291140.

16. Lu N, Samuels ME, Shi L, Baker SL, Glover SH, Sanders JM.(2004): Child day care risks of common infectious diseases revisited. Child Care Health Dev. 2004; 30: 361-368. 
Table (1): Distribution of groups of infectious diseases as recorded for children under 5 years in the family health care center

\begin{tabular}{lcc}
\hline \hline \multicolumn{1}{c}{ Groups of Infectious diseases } & No. & $\boldsymbol{\%}$ \\
\hline - Upper respiratory Tract infections & 699 & $\mathbf{2 9 . 5}$ \\
- Oro-pharyngeal infections & 467 & $\mathbf{1 9 . 7}$ \\
- Skin infections & 300 & 12.7 \\
- GE and parasitic Pneumonia & 298 & 12.6 \\
- Vaccine preventable diseases & 287 & 12.1 \\
- Pneumonia & 280 & 11.8 \\
- Urinary tract infection & 40 & 1.6 \\
\hline$\quad$ Total & $\mathbf{2 3 7 1}$ & $\mathbf{1 0 0}$ \\
\hline \hline
\end{tabular}

Table (2): Comparison between the classification of infectious diseases and the mean age of children

\begin{tabular}{|c|c|c|c|c|c|}
\hline & $\begin{array}{l}\text { Mean age } \\
\text { in months }\end{array}$ & SD & Range & $\mathbf{F}$ & Bonferoni \\
\hline Pneumonia $\mathbf{N}=280$ & 18.8 & 13.4 & $3-53$ & & I vs III, IV, VI,VII \\
\hline $\begin{array}{l}\text { Upper respiratory tract } \\
\text { infections } \mathrm{N}=699\end{array}$ & 19.9 & 10.5 & $4-58$ & & II vs III, IV, VI,VII \\
\hline $\begin{array}{l}\text { Oro-pharyngeal diseases } \\
\mathrm{N}=467\end{array}$ & 26.2 & 14.4 & $1-53$ & $171.5 \mathbf{0 . 0 0 0}$ & III vs I, II, IV, VI, VII \\
\hline $\begin{array}{l}\text { vaccine preventable diseases } \\
\mathrm{N}=\mathbf{2 8 7}\end{array}$ & 47.1 & 10.6 & $20-59$ & & $\begin{array}{l}\text { IV vs I, II, III, V, VI } \\
\text { VII }\end{array}$ \\
\hline Skin infection $\quad \mathrm{N}=300$ & 18.6 & 16.9 & $0.5-59$ & & V vs III, IV, VI, VII \\
\hline GIT infectious diseases $\mathrm{N}=298$ & 28.5 & 17.0 & $4-58$ & & VI vs I, II, IV, V \\
\hline UTI N=40 & 33.2 & 5.2 & $26-40$ & & VII vs I, II, III, IV, V \\
\hline
\end{tabular}

Chi squared test used

Table (3): Comparison between season of the year and the classification of infectious diseases

\begin{tabular}{|c|c|c|c|c|c|c|c|c|c|c|c|c|c|c|}
\hline & \multicolumn{2}{|c|}{ Pneumonia } & \multicolumn{2}{|c|}{$\begin{array}{l}\text { Upper } \\
\text { Resp. }\end{array}$} & \multicolumn{2}{|c|}{$\begin{array}{c}\text { Oro- } \\
\text { pharyngeal } \\
\text { diseases }\end{array}$} & \multicolumn{2}{|c|}{$\begin{array}{c}\text { Vaccine } \\
\text { preventable } \\
\text { diseases }\end{array}$} & \multicolumn{2}{|c|}{$\begin{array}{c}\text { Skin } \\
\text { infection }\end{array}$} & \multicolumn{2}{|c|}{$\begin{array}{c}\text { GIT } \\
\text { infectious } \\
\text { diseases }\end{array}$} & \multicolumn{2}{|c|}{ UTI } \\
\hline & $\mathbf{N}$ & $\%$ & $\mathbf{N}$ & $\%$ & $\mathbf{N}$ & $\%$ & $\mathbf{N}$ & $\%$ & $\mathbf{N}$ & $\%$ & $\mathbf{N}$ & $\%$ & $\mathbf{N}$ & $\%$ \\
\hline $\begin{array}{l}\text { Winter } \\
\mathrm{N}=941\end{array}$ & 147 & 15.6 & 410 & 43.6 & 267 & 28.4 & 54 & 5.7 & 21 & 2.2 & 36 & 3.8 & 6 & 0.7 \\
\hline $\begin{array}{l}\text { Spring } \\
\mathrm{N}=479\end{array}$ & 86 & 18.0 & 118 & 24.6 & 64 & 13.4 & 113 & 23.6 & 64 & 13.4 & 28 & 5.8 & 6 & 1.2 \\
\hline $\begin{array}{l}\text { Summer } \\
\mathbf{N}=\mathbf{3 0 7}\end{array}$ & 4 & 1.3 & 8 & 2.6 & 7 & 2.3 & 0 & 0 & 162 & 52.8 & 117 & 38.1 & 9 & 2.9 \\
\hline $\begin{array}{l}\text { Autumn } \\
\mathrm{N}=644\end{array}$ & 43 & 6.7 & 163 & 25.3 & 129 & 20.0 & 120 & 18.6 & 53 & 8.2 & 117 & 18.2 & 19 & 3.0 \\
\hline
\end{tabular}

Chi squared test used

\begin{tabular}{lllll}
\hline The Egyptian Journal of Community Medicine & Vol. 35 & No. 2 & April & 2017
\end{tabular} 
Table (4): Comparison between Mother education and the classification of infectious diseases

\begin{tabular}{|c|c|c|c|c|c|c|c|c|c|c|c|c|c|c|}
\hline \multirow{2}{*}{$\begin{array}{c}\text { Mother } \\
\text { education }\end{array}$} & \multicolumn{2}{|c|}{ Pneumonia } & \multicolumn{2}{|c|}{$\begin{array}{c}\text { Upper } \\
\text { Resp. }\end{array}$} & \multicolumn{2}{|c|}{$\begin{array}{c}\text { Oro- } \\
\text { pharyngeal } \\
\text { diseases }\end{array}$} & \multicolumn{2}{|c|}{$\begin{array}{c}\text { Vaccine } \\
\text { preventable } \\
\text { diseases }\end{array}$} & \multicolumn{2}{|c|}{$\begin{array}{c}\text { Skin } \\
\text { infection }\end{array}$} & \multicolumn{2}{|c|}{$\begin{array}{c}\text { GIT } \\
\text { infectious } \\
\text { diseases }\end{array}$} & \multicolumn{2}{|c|}{ UTI } \\
\hline & $\mathbf{N}$ & $\%$ & $\mathbf{N}$ & $\%$ & $\mathbf{N}$ & $\%$ & $\mathbf{N}$ & $\%$ & $\mathbf{N}$ & $\%$ & $\mathbf{N}$ & $\%$ & $\mathbf{N}$ & $\%$ \\
\hline $\begin{array}{c}\begin{array}{c}\text { Illiterate } \\
\mathrm{N}=176\end{array} \\
\end{array}$ & 29 & 16.5 & 38 & 21.6 & 14 & 8.0 & 7 & 4.0 & 44 & 25.0 & 38 & 21.5 & 6 & 3.4 \\
\hline $\begin{array}{c}\text { Read write } \\
\mathrm{N}=260\end{array}$ & 39 & 15.0 & 67 & 25.8 & 34 & 13.0 & 24 & 9.2 & 32 & 12.3 & 56 & 21.5 & 8 & 3.2 \\
\hline $\begin{array}{c}\text { Primary } \\
\text { prep edu. } \\
\mathrm{N}=\mathbf{8 2 7}\end{array}$ & 95 & 11.5 & 272 & 32.9 & 160 & 19.3 & 84 & 10.1 & 94 & 11.4 & 118 & 14.3 & 4 & 0.5 \\
\hline $\begin{array}{c}\text { Second- } \\
\text { High } \\
\text { education } \\
\mathbf{N}=1108\end{array}$ & 117 & 10.6 & 322 & 29.0 & 259 & 23.4 & 172 & 15.5 & 130 & 11.7 & 86 & 7.8 & 22 & 2.0 \\
\hline
\end{tabular}

Chi squared test used

Table (5): Comparison between family income and occurrence of infectious diseases

\begin{tabular}{|c|c|c|c|c|c|c|c|c|c|c|c|c|c|c|}
\hline \multirow{2}{*}{$\begin{array}{c}\text { Family income } \\
\text { (median } \\
\text { income } 600 \\
\text { pounds) }\end{array}$} & \multicolumn{2}{|c|}{ Pneumonia } & \multicolumn{2}{|c|}{$\begin{array}{l}\text { Upper } \\
\text { Resp. }\end{array}$} & \multicolumn{2}{|c|}{$\begin{array}{c}\text { Oro- } \\
\text { pharyngeal } \\
\text { diseases }\end{array}$} & \multicolumn{2}{|c|}{$\begin{array}{c}\text { Vaccine } \\
\text { preventable } \\
\text { diseases }\end{array}$} & \multicolumn{2}{|c|}{$\begin{array}{c}\text { Skin } \\
\text { infection }\end{array}$} & \multicolumn{2}{|c|}{$\begin{array}{l}\text { GIT infectious } \\
\text { diseases }\end{array}$} & \multicolumn{2}{|c|}{ UTI } \\
\hline & $\mathbf{N}$ & $\%$ & $\mathbf{N}$ & $\%$ & $\mathbf{N}$ & $\%$ & $\mathbf{N}$ & $\%$ & $\mathbf{N}$ & $\%$ & $\mathbf{N}$ & $\%$ & $\mathbf{N}$ & $\%$ \\
\hline $\begin{array}{c}<600 \mathrm{LE} \\
\mathrm{N}=1031\end{array}$ & 126 & 12.2 & 317 & 30.7 & 189 & 18.3 & 84 & 8.1 & 135 & 3.1 & 166 & 16.1 & 4 & 1.4 \\
\hline $\begin{array}{c}>=600 \mathrm{LE} \\
\mathrm{N}=1340\end{array}$ & 154 & 11.5 & 382 & 28.5 & 278 & 20.7 & 203 & 15.2 & 165 & 12.3 & 132 & 9.9 & 26 & 1.9 \\
\hline
\end{tabular}

Chi squared test used 


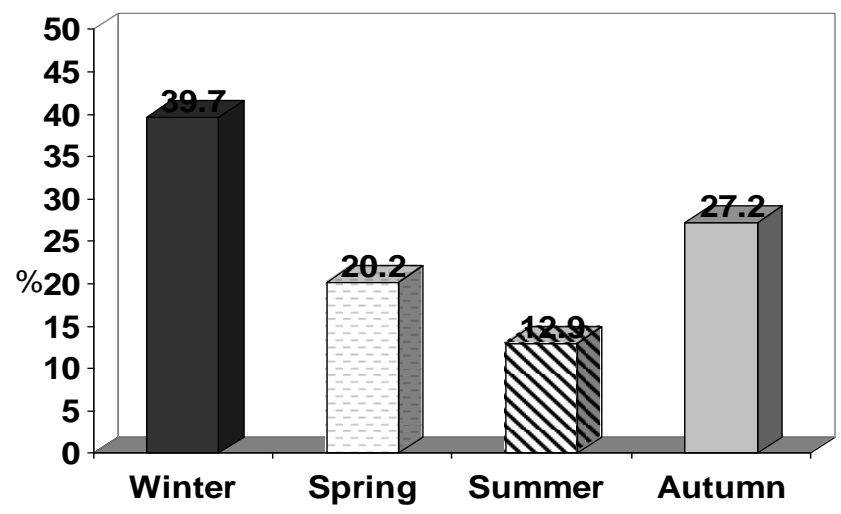

Fig. ( 1 ) Distribution of infectious diseases among children by Season of the year 